\title{
A “Double Route" to Duodenum: The Unusual Case of Healing's Bleeding Ulcer
}

\author{
Valeria D'Ovidio*, S Festa, D Lisi and ME Bazuro \\ UOSD Gastroenterology and Digestive Endoscopy, Italy
}

Submission: October 02, 2018; Published: October 15, 2018

“Corresponding author: Valeria D’Ovidio, UOSD Gastroenterology and Digestive Endoscopy, SEugenio Hospital, Rome, Italy, Email: vale_do@yahoo.it

Keywords: Hematemesis; Syncope; Epinephrine; Submucosal injection; Inflammatory Drugs; Ulcer; Urease; Duodenum;Pyloric channels Abbreviations: NSAID: Non-Steroidal Anti-Inflammatory Drugs; PPIs: Proton Pump Inhibitors; EGDS: Esophagogastroduodenoscopy; DP: Double Pylorus

\section{Case Report}

A 79-year-old woman was admitted to the emergency room of our hospital for hematemesis and syncope(Hb was $9.9 \mathrm{~g} / \mathrm{dl})$. She referred chronic use of NSAID (Non-Steroidal Anti-Inflammatory Drugs) for arthralgia without any concomitant proton pump inhibitors (PPIs). An EGDS (Esophagogastroduodenoscopy) was promptly performed and a $25 \mathrm{~mm}$, actively bleeding pre-pyloric antral ulcer was diagnosed (Forrest 1b).

A combined endoscopic treatment (epinephrine submucosal injection + clip placement) was successfully performed. A rapid urease test was negative. The patient was further treated with high dose of intravenous PPIs until she left hospital. Bleeding did not recur, and $\mathrm{Hb}$ level remained stable. At 1 month, a follow up EGDS was performed and a pre-pyloric fistula was highlighted. The duodenum could easily be entered via both of the pyloric channels.
Double pylorus (DP) is a rare condition (observed in $0.001 \%$ to $0.4 \%$ of upper gastrointestinal endoscopies) involving a double communication between the gastric antrum and the duodenal bulb [1]. Mostly, DP is a complication of a penetrating ulcer, a condition named acquired DP. Otherwise, DP occasionally occurs as a congenital abnormality, either isolated or in combination with other congenital abnormalities [2]

\section{Conclusion}

An acquired DP in our case was finally diagnosed.

\section{References}

1. Wiseman SM, Tan D, Hill HC (2005) Double pylorus: an unusual endoscopic finding. Endoscopy 37(3): 277.

2. Christien G, Branthomme JM, Volny L, Deschamps P, Morice A (1971) Double pylorus: a congenital malformation. Sem Hop 47(23): 14851488.

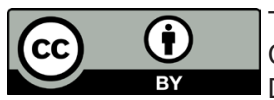

This work is licensed under Creative Commons Attribution 4.0 License DOI: 10.19080/ARGH.2018.11.555812

\section{Your next submission with JuniperPublishers} will reach you the below assets

- Quality Editorial service

- Swift Peer Review

- Reprints availability

- E-prints Service

- Manuscript Podcast for convenient understanding

- Global attainment for your research

- Manuscript accessibility in different formats

( Pdf, E-pub, Full Text, audio)

- Unceasing customer service

Track the below URL for one-step submission https://juniperpublishers.com/online-submission.php 